\title{
Anamoly Analyzing and Exploring for Wireless Sensor Networks
}

\author{
S.Theivasigamani, D.Jeyapriya, K. Anita Davamani
}

\begin{abstract}
Observing individual areas with a possibly untrusted server presents protection dangers to the checked people. To this end, we propose a security protecting area observing framework for remote sensor systems. In our framework, we plan two in system area anonymization calculations, to be specific, asset and quality-mindful calculations, that intend to empower the framework to give top notch area checking administrations for framework clients, while protecting individual area security Both calculations depend on the settled $k$-obscurity security idea, that is, an individual is undefined among $k$ people, to empower believed sensor hubs to give the total area data of observed people for our framework. The asset mindful calculation plans to limit correspondence and computational expense, while the quality-mindful calculation expects to augment the precision of the total areas by limiting their checked territories. To use the total area data to give area observing administrations, we utilize a spatial histogram approach that gauges the dissemination of the checked people dependent on the assembled total area data. The usage procedure, proposed frameworks and different perspectives are plainly talked about in proposed frameworks.
\end{abstract}

Keywords: WSN, in-network aggregation, IDM, IDSs,

,SMM, Authentication

\section{INTRODUCTION}

Remote sensor systems (WSNs) can give successful and financially feasible answers for a substantial assortment of uses, for example, wellbeing observing.

Be that as it may, just a couple of conventions consider secure in-arrange[38],[40] collection in light of an avoidance based plan, in which encryption, confirmation, and key administration are utilized. Once a sensor hub is traded off, all its related privileged insights end up noticeably open to assailants, rendering counteractive action based strategies powerless. vindictive exercises. SectionI exhibits a proposed framework in view of topology creation.

Revised Manuscript Received on July 22, 2019

S. Theivasigamani , Department of CSE, Bharath Institute of Higher Education and Research, Chennai, Tamilnadu, India. Email:dheiva94@gmail.com

D.Jeyapriya, Department of CSE, Bharath Institute of Higher Education and Research, Chennai, Tamilnadu, India. Email:priyajp8@gmail.com

K.Anita Davamani, Department of CSE, Bharath Institute of Higher Education and Research, Chennai, Tamilnadu, India. Email:anitadavamani@gmail.com
Many existing systems are followed in wireless sensor networks aspects. The famous existing techniques are as follows:

A. Auction based adaptive sensor activation algorithm for target tracking in wireless sensor networks

The quick advancement in low-control miniaturized scale electro-mechanical framework innovation, microchips, and remote correspondences has gotten colossal regard for the exploration remote sensor systems (WSNs) [1],[3],[5]

B. A semantic analysis of key management protocols for wireless sensor networks

Remote sensors are little and shoddy gadgets fueled by low-vitality batteries, outfitted with radio handsets. Such gadgets are included with asset imperative and low transmission rates.

[8],[10], ,[12]

C. The integration of mobile robotics and wireless sensor networks

The way prompting the combination of versatile mechanical autonomy and WSNs originates from two diverse fields.WSN scientists started searching for approaches to all the more proficiently utilize the vitality in the system and play out some additional undertakings in the checked field. [13], [15],[ 17]

D. On the optimality of cooperative intrusion detection for resource constrained wireless networks Interruption location frameworks are a basic piece of security for asset compelled remote systems and adhoc and sensor systems sent for crisis reaction. [14],[ 16], [18]The IDS sent in these systems vary from those utilized as a part of wired systems.

E. Adaptive service provisioning for enhanced energy efficiency and flexibility in wireless sensor networks

Programming applications for Wireless Sensor Networks (WSNs) must be facilitated both as far as the assets they expend and how they adjust to changes in the system. Administration Oriented Computing can encourage this coordination in a rich, computerized, and application-straightforward way.

Problem statements:

i) Network lifetime is low.

ii) Energy consumption is high due to transmission of redundant data.

\section{F. Extended Kalman Filters (EKF)}

The proposed convention is outfitted with two modules: IDM and SMM. Note that SMM is a vital part for the majority of WSN applications. IDM and SMM should be coordinated with each other to work successfully[19],[21],[23]. Depending on neighborhood recognition alone isn't alluring 
in light of the fact that every hub has just extremely restricted data accessible. Besides, since sensor hubs are inclined to disappointment, it is exceptionally hard to separate between crisis occasions sent by great hubs and pernicious occasions. In our proposed conspire, at whatever point IDM and SMM distinguish some irregular occasions, they have to ask for the cooperation of more sensor hubs around the occasions to settle on a ultimate choice.

\section{RESULTS \& DISCUSSIONS}

\section{A. Network Model}

To use information conglomeration, a total tree is frequently constructed first. It perform detecting assignments, acquire values and transmit them to their parent hub[20],[22], [24]. It totals (min, max, whole, normal, and so forth.) the got values and transmits the amassed esteem additionally up to hub. These total operations are performed in view of the built up parent- kid relationship, which can be displayed.

\section{B. Assumptions}

WSNs are constantly sent to screen crisis occasions, for example, timberland fires. Concerning WSNs, time synchronization still causes costly undertakings. To save focus vitality, there have been wide research endeavors on different sorts of sensor focus point booking approaches, in which a base number of focus indicates remain alert fulfill a specific component of degree. Subsequently, expect that sensor focuses may rest[7], [9] ,[11].

\section{Security Model}

The authentic regard, for example, the genuine checked typical temperature, with the objective that falsified data can satisfactorily steamed collection activities. [25],[27],[29] In case the foe just mixes a foreordained number of falsified data that are insignificantly not equivalent to clear totaled regards, this won't cause significant impact on sent applications. In this way, it will similarly consider an attack show that an adversary constantly forms falsified data with little deviations. To expect that most of center points around some peculiar events are not exchanged off.

\section{Secure In-Network Aggregation}

The handiness of the IDM is to recognize whether watched center points are noxious insider centers, while the convenience of the SMM is to screen fundamental emergency events. Note that SMM is a crucial part for most of WSN applications[2 ],[4],[6]. In addition, since sensor center points are slanted to dissatisfaction. Center point An aimlessly gets its neighbor's transmitted gathered regard and differentiations it and the foreseen commonplace range[26],[28],[30]

\section{Applications:}

It has several application especially for Surveillance in Military camps. [31],[33],[35]

- Forest fire detection

- Landslide detection

- Water quality monitoring

- Natural disaster prevention

- Industrial monitoring

- Machine health monitoring

- Industrial sense and control applications

- Water/Waste water monitoring

- Agriculture
- Smart home monitoring

- Passive localization and tracking

Table 1: Comparison between EKF and Resource aware algorithm

\begin{tabular}{|c|c|c|}
\hline S.NO & $\begin{array}{l}\text { Extended Kalman } \\
\text { Filters (EKF) }\end{array}$ & $\begin{array}{l}\text { Resource } \\
\text { algorithm }\end{array}$ \\
\hline 1. & $\begin{array}{lr}\text { The EKF } & \text { adjusted } \\
\text { procedures } & \text { from } \\
\text { analytics, } & \\
\text { specifically } & \\
\text { multivariate } & \\
\text { Taylor } & \text { Series } \\
\text { extensions, r } & \text { to } \\
\text { linearize a model } \\
\text { about a working } \\
\text { point. }\end{array}$ & $\begin{array}{l}\text { Precise limitation } \\
\text { systems, which are } \\
\text { inclined to enter } \\
\text { blunders, are asset } \\
\text { concentrated and not } \\
\text { possible on basic sensor } \\
\text { hubs without } \\
\text { adjustments. }\end{array}$ \\
\hline 2. & $\begin{array}{l}\text { The all-inclusive } \\
\text { Kalman channel } \\
\text { emerges by } \\
\text { linearizing the flag } \\
\text { show about the } \\
\text { present state gauge } \\
\text { and utilizing straight } \\
\text { Kalman channel to } \\
\text { foresee the following } \\
\text { assessment. }\end{array}$ & 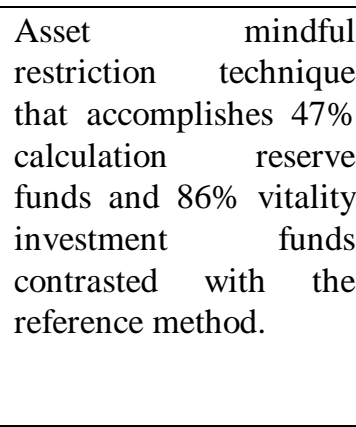 \\
\hline 3. & $\begin{array}{l}\text { The anticipated state } \\
\text { gauge and } \\
\text { estimation leftover } \\
\text { are assessed at the } \\
\text { mean of the } \\
\text { procedure and } \\
\text { estimation clamor } \\
\text { terms, which is } \\
\text { thought to be zero. }\end{array}$ & $\begin{array}{l}\text { Methodologies are } \\
\text { explicitly intended to } \\
\text { deal with vast volumes } \\
\text { of computationally } \\
\text { serious discretionarily } \\
\text { distinguishable burdens } \\
\text { submitted for preparing } \\
\text { at bunch/framework } \\
\text { frameworks including } \\
\text { various sources and } \\
\text { sinks }\end{array}$ \\
\hline
\end{tabular}

\section{CONCLUSION}

The proposed framework identifying and restricting anamoly remote sensor systems, and gives yield as EKF is the best strategy for remote systems. Notwithstanding, the approach has more broad relevance, can utilize this productive highlights and their applications in all systems administration methods. The proposed comes about demonstrate that the execution of the approach is both productive and viable for recognizing and limiting examination.

\section{REFERENCES}

[1] Kumarave A., Rangarajan K.,Algorithm for automaton specification for exploring dynamic labyrinths,Indian Journal of Science and Technology,V-6,I-SUPPL5,PP-4554-4559,Y-2013

[2] P. Kavitha, S. Prabakaran "A Novel Hybrid Segmentation Method with Particle Swarm Optimization and Fuzzy C-Mean

\section{Published By:}


Based On Partitioning the Image for Detecting Lung Cancer" International Journal of Engineering and Advanced Technology (IJEAT) ISSN: 2249-8958, Volume-8 Issue-5, June 2019

[3] Kumaravel A., Meetei O.N.,An application of non-uniform cellular automata for efficient cryptography,2013 IEEE Conference on Information and Communication Technologies, ICT 2013,V-,I-,PP-1200-1205,Y-2013

[4] Kumarave A., Rangarajan K.,Routing alogrithm over semi-regular tessellations,2013 IEEE Conference on Information and Communication Technologies, ICT 2013,V-,I-,PP-1180-1184,Y-2013

[5] P. Kavitha, S. Prabakaran "Designing a Feature Vector for Statistical Texture Analysis of Brain Tumor" International Journal of Engineering and Advanced Technology (IJEAT) ISSN: 2249-8958, Volume-8 Issue-5, June 2019

[6] Dutta P., Kumaravel A.,A novel approach to trust based identification of leaders in social networks, Indian Journal of Science and Technology,V-9,I-10,PP--,Y-2016

[7] Kumaravel A., Dutta P.,Application of Pca for context selection for collaborative filtering,Middle - East Journal of Scientific Research,V-20,I-1,PP-88-93,Y-2014

[8] Kumaravel A., Rangarajan K.,Constructing an automaton for exploring dynamic labyrinths,2012 International Conference on Radar, Communication and Computing, ICRCC 2012,V-,I-,PP-161-165,Y-2012

[9] P. Kavitha, S. Prabakaran "Adaptive Bilateral Filter for Multi-Resolution in Brain Tumor Recognition" International Journal of Innovative Technology and Exploring Engineering (IJITEE) ISSN: 2278-3075, Volume-8 Issue-8 June, 2019

[10] Kumaravel A.,Comparison of two multi-classification approaches for detecting network attacks, World Applied Sciences Journal,V-27,I-11,PP-1461-1465,Y-2013

[11] Tariq J., Kumaravel A.,Construction of cellular automata over hexagonal and triangular tessellations for path planning of multi-robots,2016 IEEE International Conference on Computational Intelligence and Computing Research, ICCIC 2016,V-,I-,PP--,Y-2017

[12] Sudha M., Kumaravel A.,Analysis and measurement of wave guides using poisson method,Indonesian Journal of Electrical Engineering and Computer Science,V-8,I-2,PP-546-548,Y-2017

[13] Ayyappan G., Nalini C., Kumaravel A.,Various approaches of knowledge transfer in academic social network,International Journal of Engineering and Technology,V-,I-,PP-2791-2794,Y-2017

[14] Kaliyamurthie, K.P., Sivaraman, K., Ramesh, S. Imposing patient data privacy in wireless medical sensor networks through homomorphic cryptosystems 2016, Journal of Chemical and Pharmaceutical Sciences92.

[15] Kaliyamurthie, K.P., Balasubramanian, P.C. An approach to multi secure to historical malformed documents using integer ripple transfiguration 2016 Journal of Chemical and Pharmaceutical Sciences92.

[16] A.Sangeetha,C.Nalini,"Semantic Ranking based on keywords extractions in the web", International Journal of Engineering \& Technology, 7 (2.6) (2018) 290-292

[17] S.V.GayathiriDevi,C.Nalini,N.Kumar,"An efficient software verification using multi-layered software verification tool "International Journal of Engineering \& Technology, 7(2.21)2018 454-457

[18] C.Nalini,ShwtambariKharabe,"A Comparative Study On Different Techniques Used For Finger - Vein Authentication", International Journal Of Pure And Applied Mathematics, Volume 116 No. 82017 , 327-333, Issn: 1314-3395

[19] M.S. Vivekanandan and Dr. C. Rajabhushanam, "Enabling Privacy Protection and Content Assurance in Geo-Social Networks", International Journal of Innovative Research in Management, Engineering and Technology, Vol 3, Issue 4, pp. 49-55, April 2018

[20] Dr. C. Rajabhushanam, V. Karthik, and G. Vivek, "Elasticity in Cloud Computing", International Journal of Innovative Research in Management, Engineering and Technology, Vol 3, Issue 4, pp. 104-111, April 2018

[21] K. Rangaswamy and Dr. C. Rajabhushanamc, "CCN-Based Congestion Control Mechanism In Dynamic Networks", International Journal of Innovative Research in Management, Engineering and Technology, Vol 3, Issue 4, pp. 117-119, April 2018.

[22] Kavitha, R., Nedunchelian, R., "Domain-specific Search engine optimization using healthcare ontology and a neural network backpropagation approach", 2017, Research Journal of Biotechnology, Special Issue 2:157-166

[23] Kavitha, G., Kavitha, R., "An analysis to improve throughput of high-power hubs in mobile ad hoc network", 2016, Journal of Chemical and Pharmaceutical Sciences, Vol-9, Issue-2: 361-363

[24] Kavitha, G., Kavitha, R., "Dipping interference to supplement throughput in MANET", 2016, Journal of Chemical and Pharmaceutical Sciences, Vol-9, Issue-2: 357-360
[25] Michael, G., Chandrasekar, A.,'Leader election based malicious detection and response system in MANET using mechanism design approach", Journal of Chemical and Pharmaceutical Sciences(JCPS) Volume 9 Issue 2, April - June 2016

[26] Michael, G., Chandrasekar, A.,'Modeling of detection of camouflaging worm using epidemic dynamic model and power spectral density", Journal of Chemical and Pharmaceutical Sciences(JCPS) Volume 9 Issue 2, April - June 2016

[27] Pothumani, S., Sriram, M., Sridhar, J., Arul Selvan, G., Secure mobile agents communication on intranet,Journal of Chemical and Pharmaceutical Sciences, volume 9, Issue 3, Pg No S32-S35, 2016

[28] Pothumani, S., Sriram, M., Sridhar, Various schemes for database encryption-a survey, Journal of Chemical and Pharmaceutical Sciences, volume 9, Issue 3, Pg NoS103-S106, 2016

[29] Pothumani, S., Sriram, M., Sridhar, A novel economic framework for cloud and grid computing, Journal of Chemical and Pharmaceutical Sciences, volume 9, Issue 3, Pg No S29-S31, 2016

[30] Priya, N., Sridhar, J., Sriram, M. "Ecommerce Transaction Security Challenges and Prevention Methods- New Approach” 2016 ,Journal of Chemical and Pharmaceutical Sciences, JCPS Volume 9 Issue 3.page no:S66-S68 .

[31] Priya, N.,Sridhar,J.,Sriram, M."Vehicular cloud computing security issues and solutions" Journal of Chemical and Pharmaceutical Sciences(JCPS) Volume 9 Issue 2, April - June 2016

[32] Priya, N., Sridhar, J., Sriram, M. "Mobile large data storage security in cloud computing environment-a new approach" JCPS Volume 9 Issue 2. April - June 2016

[33] Anuradha.C, Khanna.V, "Improving network performance and security in WSN using decentralized hypothesis testing "Journal of Chemical and Pharmaceutical Sciences(JCPS) Volume 9 Issue 2, April - June 2016.

[34] Anuradha.C, Khanna.V, "A novel gsm based control for e-devices" Journal of Chemical and Pharmaceutical Sciences(JCPS) Volume 9 Issue 2, April - June 2016

[35] Anuradha.C, Khanna.V, "Secured privacy preserving sharing and data integration in mobile web environments " Journal of Chemical and Pharmaceutical Sciences(JCPS) Volume 9 Issue 2, April - June 2016.

[36] Sundarraj, B., Kaliyamurthie, K.P. Social network analysis for decisive the ultimate classification from the ensemble to boost accuracy rates 2016 International Journal of Pharmacy and Technology 8

[37] Sundarraj, B., Kaliyamurthie, K.P. A content-based spam filtering approach victimisation artificial neural networks 2016 International Journal of Pharmacy and Technology 83 .

[38] Sundarraj, B., Kaliyamurthie, K.P. Remote sensing imaging for satellite image segmentation 2016 International Journal of Pharmacy and Technology8 3

[39] Sivaraman, K., Senthil, M. Intuitive driver proxy control using artificial intelligence 2016 International Journal of Pharmacy and Technology84.

[40] Sivaraman, K., Kaliyamurthie, K.P. Cloud computing in mobile technology 2016 Journal of Chemical and Pharmaceutical Sciences92.

[41] Sivaraman, K., Khanna, V. Implementation of an extension for browser to detect vulnerable elements on web pages and avoid click jacking 2016 Journal of Chemical and Pharmaceutical Sciences92.

\section{AUTHORS PROFILE}

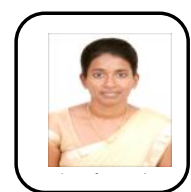

C.Theivasigamani, Assistant Professor, Department of Computer Science \& Engineering, Bharath Institute of Higher Education and Research, Chennai, India

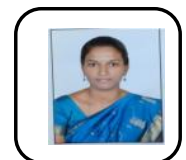

D.Jeyapriya Assistant Professor, Department of Computer Science \& Engineering, Bharath Institute of Higher Education and Research, Chennai, India

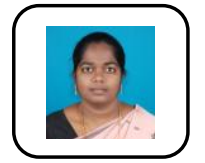

K.AnitaDavamani Assistant Professor, Department of Computer Science \& Engineering, Bharath Institute of Higher Education and Research, Chennai, India 